\title{
RANCANG BANGUN SISTEM PENDETEKSI DAN PEMANTAUAN REKAM MEDIS PENYAKIT DIABETES SECARA NON INVASIVE BERBASIS KOMPUTER
}

\author{
Febrisia Lidia ${ }^{1}$, Sabar Setiawidayat ${ }^{2}$, Dedi Usman Effendy ${ }^{3}$ \\ 1Fakultas Teknik, Jurusan Teknik Elektro, Universitas Widyagama Malang \\ 2Fakultas Teknik, Jurusan Teknik Elektro, Universitas Widyagama Malang \\ ${ }^{3}$ Fakultas Teknik, Jurusan Teknik Elektro, Universitas Widyagama Malang \\ Email: $\underline{\text { lidiafeb@gmail.com }}$
}

\begin{abstract}
Abstrak
Penyakit diabetes melitus harus dipantau secara kontinu dan pemeriksaan kadar gula darah secara invasive (melukai kulit), pasien berpenyakit diabetes sangat berbahaya karena dapat menimbulkan luka yang susah sembuh. Peralatan dalam bidang kedokteran untuk pemeriksaan gula darah dalam tubuh telah mengalami berbagai pengembangan, salah satunya pengukuran gula darah dalam tubuh dengan cara non invasive melalui media urine. Namun hal tersebut kurang akurat, maka diperlukan sensor yang dapat mendeteksi perubahan warna kemudian dibaca nilai RGB nya oleh mikrokontroler. Salah satu sensor warna yang digunakan salah satunya TCS3200 dan mikrokontroler Atmega8. Berbagai penelitian pengukuran kadar gula darah dalam urine hanya ditampilkan pada layar LCD dan tidak meyimpan data hasil pengukuran. Dengan permasalahan yang ada, diperlukan suatu alat yang mengeluarkan hasil output pengukuran kadar gula darah dalam urine dan ditampilkan dengan aplikasi database rekam medis pasien sehingga dapat di monitoring secara kontinu.
\end{abstract}

Kata Kunci: diabetes, urine strip, sensor warna TCS3200, mikrokontroler Atmega8.

\begin{abstract}
Diabetes mellitus must be monitored continuously and check blood sugar levels invasive (injuring the skin), patients with diabetes are very dangerous because it can cause wounds that are difficult to heal. Equipment in the medical field for examining blood sugar in the body has undergone various developments, one of which is the measurement of blood sugar in the body in a non-invasive way through urine media. $B u t$ this is not accurate, it requires a sensor that can detect color changes and then read the RGB value by the microcontroller. One of the color sensors used is one of them TCS3200 and Atmega8 microcontroller. Various studies on measuring blood sugar levels in urine are only displayed on the LCD screen and do not store measurement data. With the existing problems, we need a tool that outputs the measurement results of blood sugar levels in urine and is displayed with the application of the patient's medical record database so that it can be monitored continuously.
\end{abstract}

Keywords: diabetes, urine strip, TCS3200 color sensor, Atmega8 microcontroller. 


\section{PENDAHULUAN}

Seorang pasien yang mengalami penyakit diabetes mellitus dapat dideteksi dengan kandungan glukosa darah. Dalam pemeriksaan untuk pengambilan sampel pasien dilakukan dengan cara invasive (melukai tubuh), dimana pengambilan sampel darah dilakukan dengan penusukan melalui jari atau lengan pasien. Jika pasien terdiagnosa DM (Diabetes Melitus) harus segera dilakukan pengontrolan secara rutin karena dapat berakibat amputasi, kebutaan dan efek yang lainnya seperti hipertensi, jantung ataupun gagal ginjal. Infeksi dapat terjadi karena penderita DM tidak bisa memproduksi insulin dalam tubuhnya. Insulin sangat penting dalam penyerapan dan pengolahan glukosa dalam sel-sel tubuh untuk menghasilkan energi. Kekurangan energi pada bagian luka atau sel yang rusak akan menyebabkan penyembuhan yang lama bahkan infeksi [1] [2].

Sebagai alternatif, pendekatan untuk mengukur konsentrasi glukosa dalam cairan tubuh termasuk urine, air liur dan cairan air mata memiliki potensi besar untuk diagnosis non-invasive (pendiagnosaan penyakit tanpa melukai tubuh pasien) penyakit diabetes. Tes urine sebagai diagnosis untuk diabetes telah dilakukan selama lebih seabad. Pada tahun 1941, Divisi Ames Miles Laboratories (seorang dokter bernama Walter Ames Compton), di Elkhart, Indiana, memperkenalkan tablet tes standar untuk gula tertentu yang melibatkan sulfat tembaga yang disebut Larutan Benedict. Salah satunya CLINITEST, tablet dapat ditambahkan ke beberapa tetes urine dan warna yang dihasilkan dari biru terang sampai jingga yang mengindikasikan tingkat glukosa dalam urine. Uji benedict jika hanya dilakukan dengan cara yang seperti biasa maka data kadar gula yang didapatkan hanya semi kuantitatif, data berupa presentase gula pada urine. Sedangkan informasi kadar gula wajib diketahui secara kuantitatif dalam satuan $\mathrm{mg} / \mathrm{dL}$. Melihat permasalahan tersebut dilakukanlah penelitian tentang alat ukur kadar gula air urine yang direaksikan menggunakan larutan pereduksi glukosa yaitu reagen benedict kemudian ditinjau nilai kekeruhannya menggunakan sensor cahaya dan hasil dari pengukuran ditampikan dengan menggunakan LCD [3][4]. Berdasarkan latar belakang yang telah dijelaskan, maka permasalahan yang diangkat pada penelitian ini adalah bagaimana membuat dan merancang sistem detektor diabetes secara noninvasive sehingga informasinya dapat ditampilkan dalam sebuah database rekam medis.

Dari masalah di atas Tujuan dari penelitian ini adalah merancang Sistem Detektor dan Monitoring Rekam Medis Penyakit Diabetes Pada Pasien Secara Non Invasive Berbasis PC. Sehingga dapat menghasilkan detektor diabetes yang dapat mendiagnosis pasien secara non-invasive (pendiagnosaan penyakit tanpa melukai tubuh pasien) serta data kadar gula yang dihasilkan memiliki hasil yang kuantitatif yang dapat dilihat dan terekam dalam database reakam medis.

\section{STUDI PUSTAKA}

\subsection{Diabetes Mellitus}

Diabetes melitus, penyakit gula atau penyakit kencing manis, diketahui sebagai suatu penyakit yang disebabkan oleh adanya gangguan menahun terutama pada sistem metabolisme karbohidrat, lemak dan juga protein dalam tubuh [5].

Organisasi Kesehatan Dunia (WHO) merekomendasikan tiga bentuk diabetes mellitus yaitu: 
a. Diabetes mellitus tipe 1

Diabetes mellitus tipe 1 adalah sebuah kondisi tubuh dimana tubuh tidak mampu untuk menghasilkan insulin sendiri sehingga diperlukan injeksi insulin dari luar.

b. Diabetes mellitus tipe 2

Diabetes mellitus tipe 2 atau sering juga disebut dengan non insuline dependent diabetes mellitus (NDDM) merupakan penyakit diabetes yang disebabkan terjadinya resistansi tubuh terhadap efek insulin yang diproduksi sel beta pankreas.

c. Diabetes mellitus gestasional

Diabetes mellitus gestasional didefinisikan sebagai gangguan toleransi glukosa berbagai tingkat yang diketahui pertama kali saat hamil tanpa membedakan apakah penderita perlu mendapat insulin atau tidak.

\subsection{Urine Strip}

Urine Test Strip berfungsi untuk mengukur parameter kimia tubuh melalui sampel urine bersama alat urine analysis Combostik R300 atau dengan pengamatan visual langsung dengan membandingkan hasil pada chart di botol urine strip [5].

\subsection{Sensor warna TCS3200}

TCS3200 merupakan IC yang dapat diprogram yang berguna untuk mengkonversi warna cahaya ke frekuensi dengan output berbentuk sinyal kotak. Ada dua komponen utama pembentuk alat ini, yaitu photodiode dan pengkonversi arus ke frekuensi [4].

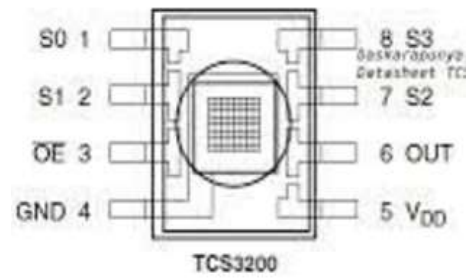

Gambar 2.1 Konfigurasi Pin TCS3200

\subsection{Mikrokontroler Atmega8}

AVR ATMega8 adalah mikrokontroler CMOS 8-bit berarsitektur AVR RISC yang memiliki 8K byte in-System Programmable Flash. Mikrokontroler dengan konsumsi daya rendah ini mampu mengeksekusi instruksi dengan kecepatan maksimum 16MIPS pada frekuensi $16 \mathrm{MHz}$.

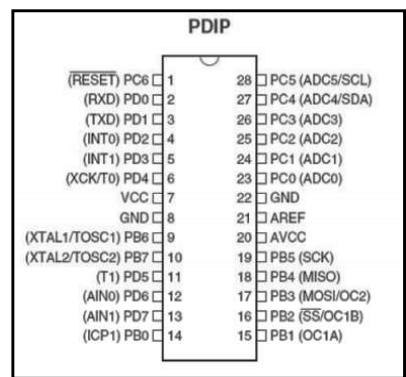

Gambar 2.3 Konfigurasi Pin Atmega8 


\subsection{Borland Delphi 7}

Delphi adalah suatu bahasa pemograman (development language) yang digunakan untuk merancang suatu aplikasi program. Delphi termasuk dalam pemrograman bahasa tingkat tinggi (high level lenguage). Maksud dari bahasa tingkat tinggi yaitu perintah-perintah programnya menggunakan bahasa yang mudah dipahami oleh manusia. Bahasa pemrograman Delphi disebut bahasa prosedural artinya mengikuti urutan tertentu.

Sebagaian besar pengembang Delphi menuliskan dan mengkompilasi kode program di dalam lingkungan pengembang aplikasi atau Integrated Development Environment (IDE). Lingkungan kerja IDE ini menyediakan sarana yang diperlukan untuk merancang, membangun, mencoba, mencari atau melacak kesalahan serta mendistribusikan aplikasi. Sarana-sarana inilah yang memungkinkan pembuatan prototipe aplikasi menjadi lebih mudah dan waktu yang diperlukan untuk mengembangkan aplikasi menjadi lebih singkat [6].

\section{METODE}

\subsection{Blok Diagram Sistem}

Pada gambar 3.1 blog diagram sistem detektor dan monitoring diabetes terbagi dalam 5 bagian, yaitu urine strip, sensor warna TCS3200, IC mikrokontroler Atmega8, USB serial dan PC (Personal Computer).

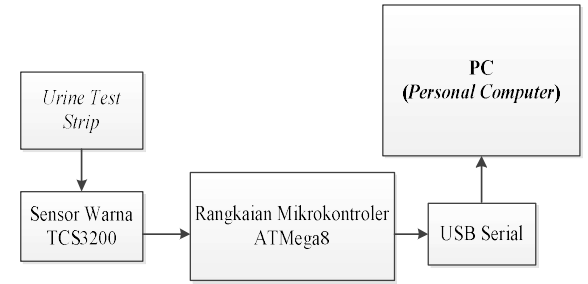

Gambar 3.1 Blok diagram sistem detektor

\subsection{Perancangan Hardware}

Perancangan dan pembuatan perangkat keras terdiri dari rangkaian mikrokontroler, rangkaian sensor warna dan rangkaian komunikasi serial.

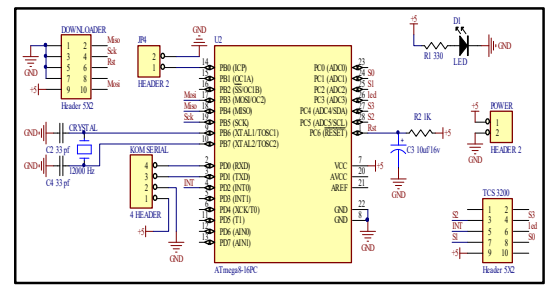

Gambar 3.2 Schematice Keseluruhan Sistem

\subsubsection{Rangkaian mikrokontroler Atmega8}

Menurut Gambar 3.3 rangkaian mikrokontroler terbagi 3 bagian, yaitu rangkaian downloader, rangkaian reset dan rangkaian kristal. 


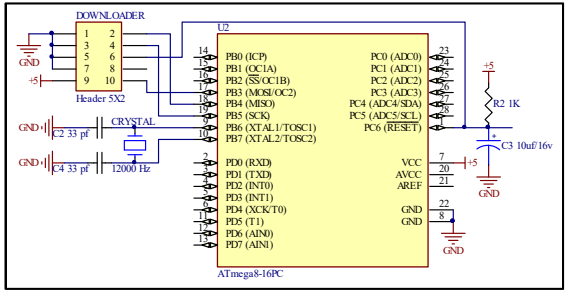

Gambar 3.3 Rangkaian mikrokontroler

\subsubsection{Sensor warna TCS3200}

Pin yang terhubung seperti terlihat pada gambar (dihubungkan dengan i/o mikrokontroller pada pin C0 - C5 kecuali pin INT) . khusus pin INT (interupt) dari sensor dihubungkan dengan input interupt pada mikrokontroller yaitu dipilih pin D2 yang berfungsi sebagai pin INTO.

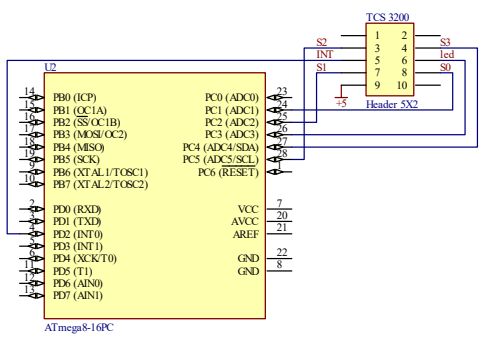

Gambar 3.4 Rangkaian sensor warna

\subsection{Perancangan software}

\subsubsection{Perancangan perangkat lunak mikrokontroler}

Pada gambar 3.5 ditunjukan bentuk dari flowchart mikrokontroler.

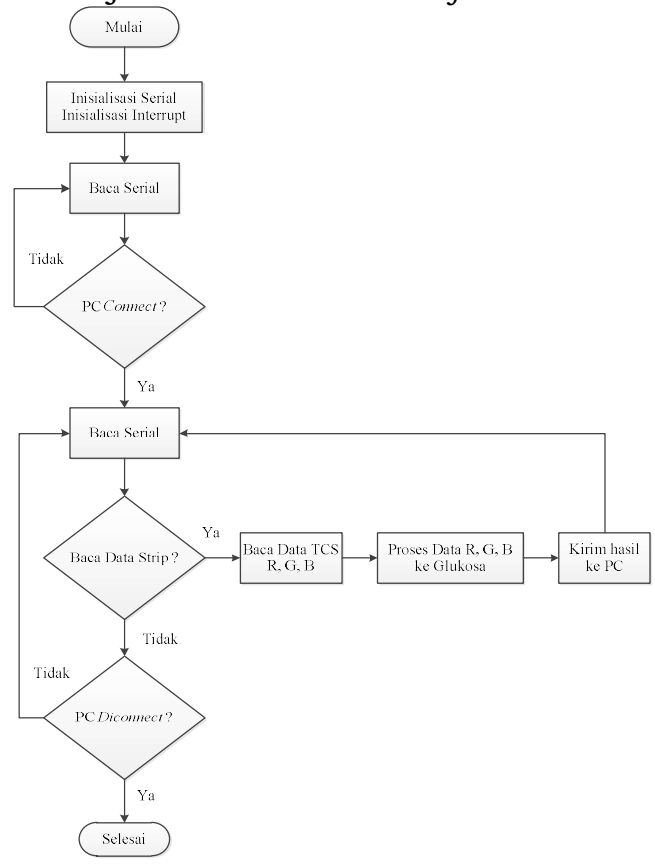

Gambar 3.5 Flowchart mikrokontroler 


\subsubsection{Perancangan aplikasi database rekam medis}

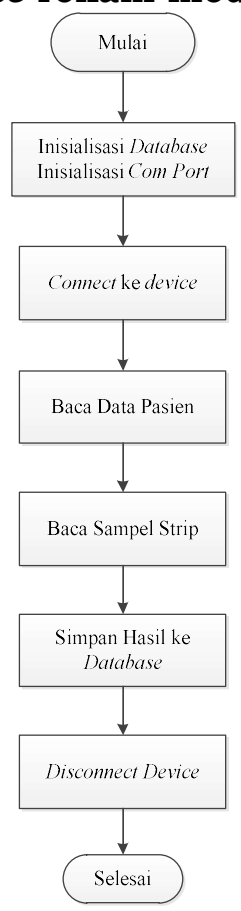

Gambar 3.6 Aplikasi database

\subsection{Pembuatan Perangkat keras}

Gambar 3.7 memperlihatkan implementasi dari perangkat yang dirancang

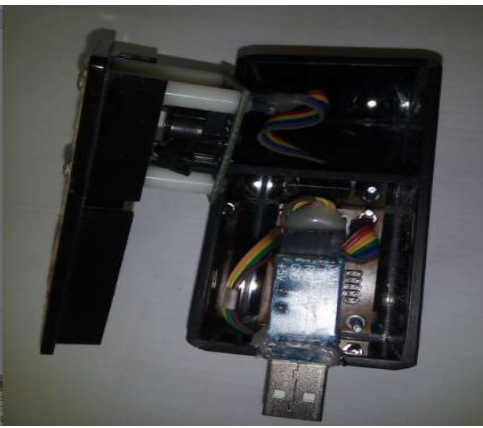

Gambar 3.7 Hasil implementasi alat

\subsection{Pembuatan perangkat lunak}

Pada gambar 3.8 ditunjukkan hasil tampilan pembacaan mikrokontroler dari sensor, sedangkan tampilan dari aplikasi database rekam medis pasien dapat dilihat pada gambar 3.9.

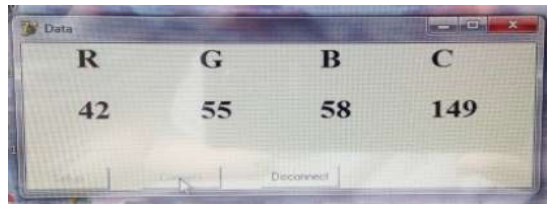

Gambar 3.8 Tampilan nilai RGB 


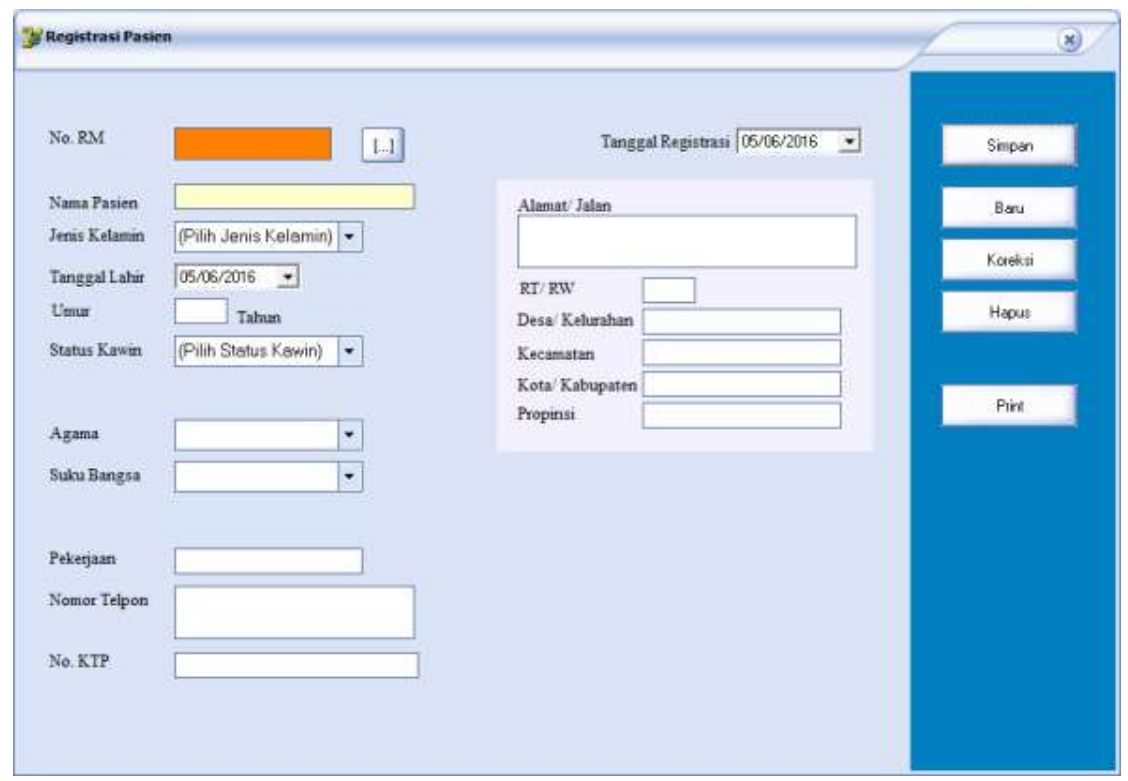

Gambar 3.9 Tampilan aplikasi database rekam medis

\section{HASIL DAN PEMBAHASAN}

\subsection{Pengujian urine strip, sensor warna dan mikrokontroler}

Sistem kerja alat detektor diabetes dimulai dari ketika sensor TCS3200 mendeteksi perubahan warna yang dihasilkan oleh sampel strip. Kemudian perubahan warna pada sampel strip tersebut dikonversikan menjadi suatu nilai variabel Red Green Blue (RGB), dimana nilai yang dihasilkan dapat berbeda-beda berdasarkan tingkat kepekatan warna yang dihasilkan oleh sampel strip. Diperlukan waktu lebih kurang \pm 5 detik untuk sampel urine meresap di urine strip sebelum urine strip tersebut dimasukkan kedalam detektor sensor warna. Selanjutnya nilai RGB tersebut dibaca dan diolah oleh mikrontroler untuk dapat mengetahui kadar glukosa yang terkandung pada urine test strip tersebut.

Tabel 4.1 Sampel Pasien Pada Saat Puasa

\begin{tabular}{|c|c|c|c|c|c|}
\hline NO & Kode Sample & $\mathbf{R}$ & $\mathbf{G}$ & $\mathbf{B}$ & $\mathbf{C}$ \\
\hline 1 & CM1 & 39 & 48 & 39 & 124 \\
\hline 2 & CM2 & 56 & 40 & 32 & 128 \\
\hline 3 & CM3 & 54 & 51 & 41 & 148 \\
\hline 4 & CM4 & 42 & 61 & 65 & 166 \\
\hline 5 & CM5 & 43 & 59 & 49 & 155 \\
\hline 6 & CM6 & 28 & 25 & 18 & 75 \\
\hline 7 & CM7 & 39 & 65 & 60 & 167 \\
\hline 8 & CM8 & 43 & 62 & 62 & 163 \\
\hline 9 & CM9 & 36 & 39 & 31 & 104 \\
\hline 10 & CM10 & 34 & 29 & 24 & 87 \\
\hline 11 & CM11 & 51 & 37 & 30 & 118 \\
\hline 12 & CM12 & 41 & 62 & 64 & 164 \\
\hline 13 & CM13 & 44 & 68 & 67 & 178 \\
\hline 14 & CM14 & 44 & 62 & 65 & 166 \\
\hline
\end{tabular}


Tabel 4.2 Sampel Pasien Pada Saat 2 Jam PP Setelah Makan

\begin{tabular}{|c|c|c|c|c|c|}
\hline NO & Kode Sample & $\mathbf{R}$ & $\mathbf{G}$ & $\mathbf{B}$ & $\mathbf{C}$ \\
\hline 1 & CM1 & 41 & 55 & 56 & 149 \\
\hline 2 & CM2 & 5 & 49 & 44 & 146 \\
\hline 3 & CM3 & 42 & 55 & 58 & 149 \\
\hline 4 & CM4 & 38 & 62 & 56 & 160 \\
\hline 5 & CM5 & 29 & 22 & 23 & 77 \\
\hline 6 & CM6 & 37 & 32 & 31 & 102 \\
\hline 7 & CM7 & 54 & 33 & 26 & 114 \\
\hline 8 & CM8 & 40 & 59 & 60 & 156 \\
\hline 9 & CM9 & 33 & 28 & 24 & 85 \\
\hline 10 & CM10 & 30 & 23 & 24 & 79 \\
\hline 11 & CM11 & 26 & 18 & 21 & 64 \\
\hline 12 & CM12 & 43 & 62 & 62 & 164 \\
\hline 13 & CM13 & 38 & 39 & 28 & 106 \\
\hline 14 & CM14 & 39 & 54 & 62 & 147 \\
\hline
\end{tabular}

\subsection{Pengujian Keseluruhan Sistem}

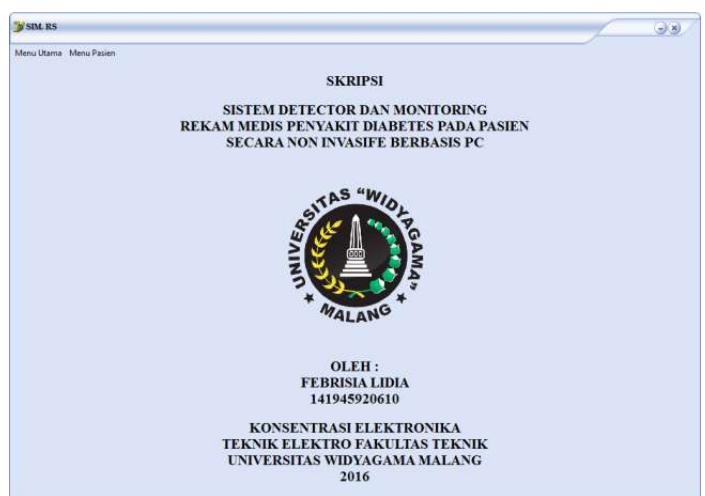

Gambar 4.2 Tampilan hasil perancangan software

Pengelompokan data hasil sampel urine pasien yang telah diukur seperti pada tabel 4.1 dan 4.2, maka dilakukan fungsi logika fuzzy dibagi 3 tahap, sebagai berikut:

1. Menentukan input data nilai RGB

Tabel 4.3 Pengelompokkan Nilai RGB Merah (R) $26 \rightarrow 56$

\begin{tabular}{|l|l|l|l|}
\hline Rendah & 26 & 33,5 & 41 \\
\hline Sedang & 33,5 & 41 & 48,5 \\
\hline Tinggi & 41 & 48,5 & 56 \\
\hline
\end{tabular}

Hijau (G) $18 \rightarrow 68$

\begin{tabular}{|l|l|l|l|}
\hline Rendah & 18 & 30,5 & 43 \\
\hline Sedang & 30,5 & 43 & 55,5 \\
\hline Tinggi & 43 & 55,5 & 68 \\
\hline
\end{tabular}

Biru (B) $18 \rightarrow 67$

\begin{tabular}{|l|l|l|l|}
\hline Rendah & 18 & 30,25 & 42,5 \\
\hline Sedang & 30,25 & 42.5 & 54,5 \\
\hline Tinggi & 42,5 & 54,5 & 67 \\
\hline
\end{tabular}


2. Menentukan rule logika RGB

Hasil dari penentuan pengelompokan pada tabel 4.3, maka dapat menentukan rule logika fuzzy seperti yang ditampilkan pada tabel 4.4.

Tabel 4.4 Rule Logika

\begin{tabular}{|c|c|c|c|c|}
\hline \multirow{2}{*}{ NO. } & \multicolumn{3}{|c|}{ RULE LOGIKA } & \multirow{2}{*}{ KATEGORI } \\
\cline { 2 - 4 } & RED & GREEN & BLUE & \\
\hline 1 & $\mathrm{R}$ & $\mathrm{R}$ & $\mathrm{R}$ & \\
\hline 2 & $\mathrm{R}$ & $\mathrm{R}$ & $\mathrm{S}$ & \\
\hline 3 & $\mathrm{R}$ & $\mathrm{R}$ & $\mathrm{T}$ & ++++ \\
\hline 4 & $\mathrm{R}$ & $\mathrm{S}$ & $\mathrm{R}$ & \\
\hline 5 & $\mathrm{R}$ & $\mathrm{S}$ & $\mathrm{S}$ & \\
\hline 6 & $\mathrm{R}$ & $\mathrm{S}$ & $\mathrm{T}$ & \\
\hline 7 & $\mathrm{R}$ & $\mathrm{T}$ & $\mathrm{R}$ & \\
\hline 8 & $\mathrm{R}$ & $\mathrm{T}$ & $\mathrm{S}$ & \\
\hline 9 & $\mathrm{R}$ & $\mathrm{T}$ & $\mathrm{T}$ & +++ \\
\hline 10 & $\mathrm{~S}$ & $\mathrm{R}$ & $\mathrm{R}$ & \\
\hline 11 & $\mathrm{~S}$ & $\mathrm{R}$ & $\mathrm{S}$ & \\
\hline 12 & $\mathrm{~S}$ & $\mathrm{R}$ & $\mathrm{T}$ & \\
\hline 13 & $\mathrm{~S}$ & $\mathrm{~S}$ & $\mathrm{R}$ & \\
\hline 14 & $\mathrm{~S}$ & $\mathrm{~S}$ & $\mathrm{~S}$ & \\
\hline 15 & $\mathrm{~S}$ & $\mathrm{~S}$ & $\mathrm{~T}$ & ++ \\
\hline 16 & $\mathrm{~S}$ & $\mathrm{~T}$ & $\mathrm{R}$ & \\
\hline 17 & $\mathrm{~S}$ & $\mathrm{~T}$ & $\mathrm{~S}$ & \\
\hline 18 & $\mathrm{~S}$ & $\mathrm{~T}$ & $\mathrm{~T}$ & \\
\hline 19 & $\mathrm{~T}$ & $\mathrm{R}$ & $\mathrm{R}$ & \\
\hline 20 & $\mathrm{~T}$ & $\mathrm{R}$ & $\mathrm{S}$ & \\
\hline 21 & $\mathrm{~T}$ & $\mathrm{R}$ & $\mathrm{T}$ & \\
\hline 22 & $\mathrm{~T}$ & $\mathrm{~S}$ & $\mathrm{R}$ & \\
\hline 23 & $\mathrm{~T}$ & $\mathrm{~S}$ & $\mathrm{~S}$ & \\
\hline 24 & $\mathrm{~T}$ & $\mathrm{~S}$ & $\mathrm{~T}$ & \\
\hline 25 & $\mathrm{~T}$ & $\mathrm{~T}$ & $\mathrm{R}$ & \\
\hline 26 & $\mathrm{~T}$ & $\mathrm{~T}$ & $\mathrm{~S}$ & \\
\hline 27 & $\mathrm{~T}$ & $\mathrm{~T}$ & $\mathrm{~T}$ & \\
\hline & & & & \\
\hline
\end{tabular}

3. Menentukan nilai output

Berdasarkan pada tabel 4.4, maka nilai output urine strip ditunjukkan pada tabel 4.5.

Tabel 4.5 Nilai Output urine strip pada Sistem Detektor Output $0 \rightarrow 2000$

\begin{tabular}{|c|c|c|c|}
\hline Kategori & \multicolumn{3}{|c|}{ Nilai $\mathbf{M g / d 1}$ (mmol/L) } \\
\hline $\boldsymbol{-}$ & 0 & 50 & 100 \\
\hline+ & 100 & 175 & 250 \\
\hline++ & 250 & 375 & 500 \\
\hline+++ & 500 & 750 & 1000 \\
\hline++++ & 1000 & 1500 & 2000 \\
\hline
\end{tabular}


Setelah pengambilan sampel urine pasien dan dilakukannya pengukuran sampel urine pada pasien penderita diabetes melitus, maka hasil dari pengukuran dapat dilihat pada tabel 4.6 dan 4.7.

Tabel 4.6 Hasil pengukuran pada saat puasa

\begin{tabular}{|c|c|c|c|c|c|}
\hline NO & $\begin{array}{c}\text { RANGE OUPUT } \\
\text { ALAT UKUR } \\
\text { (mg/d1) }\end{array}$ & $\begin{array}{c}\text { HASIL ALAT } \\
\text { UKUR } \\
\text { (mg/dl) }\end{array}$ & KATEGORI & $\begin{array}{c}\text { HASIL } \\
\text { LAB } \\
\text { (mg/d1) }\end{array}$ & KATEGORI \\
\hline 1 & $500-750-1000$ & 612 & +++ & 50 & + \\
\hline 2 & $100-175-250$ & 128 & + & 50 & + \\
\hline 3 & $0-50-100$ & 51 & - & 49 & - \\
\hline 4 & $100-175-250$ & 150 & + & 49 & - \\
\hline 5 & $100-175-250$ & 203 & + & 50 & + \\
\hline 6 & $1000-1500-2000$ & 1077 & ++++ & 100 & ++ \\
\hline 7 & $250-375-500$ & 371 & ++ & 49 & - \\
\hline 8 & $100-175-250$ & 141 & + & 49 & - \\
\hline 9 & $1000-1500-2000$ & 1165 & ++++ & 50 & + \\
\hline 10 & $1000-175-250$ & 1538 & + & 100 & + \\
\hline 11 & $100-175-250$ & 175 & + & 50 & - \\
\hline 12 & $100-175-250$ & 160 & + & 49 & - \\
\hline 13 & $0-50-100$ & 68 & - & 49 & - \\
\hline 14 & $0-50-100$ & 92 & - & 49 & - \\
\hline JUMLAH & 5931 & & 793 & \\
\hline$\mu=$ NILAI RATA-RATA & 423,64 & & 57 & \\
\hline VARIANCE & $234.926,55$ & & & \\
\hline SD & & 484,692 & & & \\
\hline SE & 129,539 & & & \\
\hline
\end{tabular}

Tabel 4.7 Hasil pengukuran pada saat setelah 2 jam pp

\begin{tabular}{|l|l|l|l|l|l|}
\hline NO & $\begin{array}{c}\text { RANGE OUTPUT } \\
\text { ALAT UKUR }\end{array}$ & $\begin{array}{c}\text { HASIL ALAT } \\
\text { UKUR }\end{array}$ & KATEGORI & $\begin{array}{c}\text { HASIL } \\
\text { ALAT LAB }\end{array}$ & KATEGORI \\
\hline 1 & $250-375-500$ & 483 & ++ & 49 & - \\
\hline 2 & $0-50-100$ & 90 & - & 49 & - \\
\hline 3 & $250-375-500$ & 450 & ++ & 49 & - \\
\hline 4 & $250-375-500$ & 412 & ++ & 49 & - \\
\hline 5 & $1000-1500-2000$ & 1.462 & ++++ & 100 & ++ \\
\hline 6 & $1000-1500-2000$ & 1.017 & ++++ & 100 & ++ \\
\hline 7 & $100-175-250$ & 169 & + & 49 & - \\
\hline 8 & $250-375-500$ & 266 & ++ & 49 & - \\
\hline 9 & $1000-1500-2000$ & 1.538 & ++++ & 100 & ++ \\
\hline 10 & $1000-1500-2000$ & 1.538 & ++++ & 100 & ++ \\
\hline 11 & $1000-1500-2000$ & 1.125 & ++++ & 1.000 & ++++ \\
\hline 12 & $100-175-250$ & 141 & + & 49 & - \\
\hline 13 & $500-750-1000$ & 970 & +++ & 50 & + \\
\hline 14 & $500-750-1000$ & 631 & +++ & 49 & - \\
\hline JUMLAH & 10.292 & & 1.842 & \\
\hline M N NILAI RATA-RATA & 735 & & 132 & \\
\hline VARIANCE & $259.707,68$ & & & \\
\hline SD & 509,615 & & & \\
\hline SE & & 136,200 & & & \\
\hline
\end{tabular}


Tampilan grafik untuk kondisi saat puasa dari tabel. 4.6 dan pada saat setelah 2 jam pp dari tabel 4.7 ditunjukkan pada gambar 4.3 dan gambar 4.4

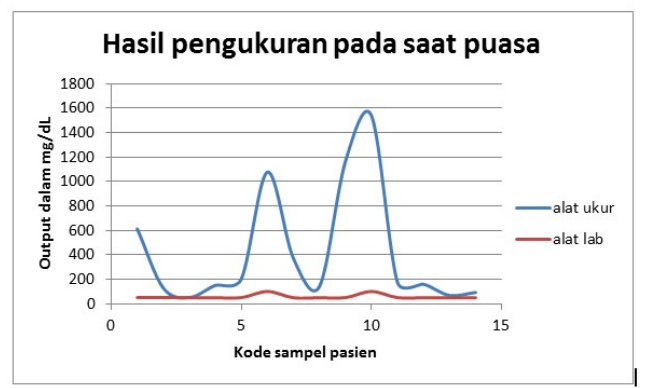

Gambar 4.3 Grafik hasil perbandingan pada saat puasa

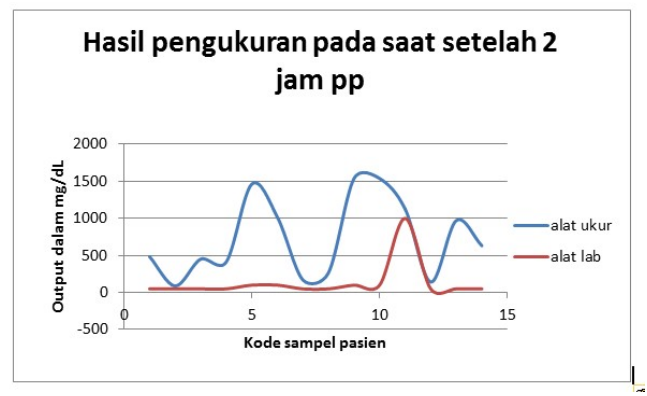

Gambar 4.4 Grafik hasil perbandingan pada saat setelah 2 jam pp

Berdasarkan dari gambar 4.3 dan 4.4, maka terdapat perbedaan yang signifikan antara hasil pengukuran pada alat ukur dan alat laboratorium, disebabkan sebagai berikut:

1. Hasil output urine strip kondisi normal pada dua alat ini berbeda yaitu kondisi normal pasien yang tidak terdeteksi diabetes termasuk kategori negatif (-) yang ditampilkan pada alat ukur berkisar $50-100 \mathrm{mg} / \mathrm{dL}(2,5-5 \mathrm{mmo} / \mathrm{L})$, sedangkan pada alat urine analyzer laboratorium hanya berkisar $<50 \mathrm{mg} / \mathrm{dL}$ (dibawah 50).

2. Frekuensi output pada alat ukur lebih besar dibandingkan dengan frekuensi output alat laboratorium yang disebabkan perbedaan hasil output dari kedua urine urine strip.

3. Pada alat laboratorium di saat kondisi sampel urine hasil outputnya masuk dalam kategori positif $(+)$ baik itu pada kategori positif $1(+)$, positif $2(++)$, positif $3(+++)$ dan positif $4(++++)$ hanya keluaran nilai saja 50, 100, 300 dan 1000 $\mathrm{mg} / \mathrm{dl}$. Sedangkan pada alat ukur di saat kondisi sampel urine hasil outputnya bisa bervariasi seperti 128, 1017, 203 dan lain sebagainya dikarenakan fungsi fuzzy yang digunakan sehingga kesensitifitasi alat ukur sangat tinggi.

\section{KESIMPULAN}

Kesimpulan yang penulis peroleh setelah melaksanakan penelitian ini adalah sebagai berikut:

1. Perangkat yang dirancang ini mampu mendeteksi kadar glukosa dalam urine.

2. Penggunaan metode fuzzy dapat menghasilkan tingkat kategori negatif atau positif penyakit diabetes. 
3. Sistem detektor diabetes secara non invasive dapat disimpan dalam database rekam medis sehingga pengukuran gula darah pada urine pasien dapat direkam secara kontinu.

4. Data informasi kadar gula darah pada pasien penyakit diabetes dapat dilihat dan dihitung kadar glukosa dalam urine dan terekam dalam database rekam medis pasien, sehingga dapat dipanggil kembali bila pasien melakukan monitoring selanjutnya.

5. Sensor warna TCS3200 dapat mendeteksi warna RGB dengan cukup baik sehingga dapat menghasilkan nilai RGB yang dibaca oleh mikrokontroler.

6. Cara menghubungkan komunikasi antara mikrokontroler dengan PC yaitu menggunakan metoda fuzzy dan dipresentasikan dengan aplikasi program Borland Delphi.

\section{DAFTAR RUJUKAN}

[1] W. H. Organization, World Health Organization Diabetes Fact Sheet. 2011.

[2] S. John, The Pursuit Of Noninvasive Glucose:"Hunting The Deceitful Turkey." Ankara, 2011.

[3] T. K. G. Darah, "Skripsi Diajukan Untuk Memenuhi Persyaratan Memperoleh Gelar Sarjana Keperawatan (S.Kep),” p. 125, 2009.

[4] E. Satria, "Rancang Bangun Alat Ukur Kadar Gula Darah Non- Invasive Berbasis Mikrokontroler At89s51 Dengan Mengukur Tingkat Kekeruhan Spesimen Urine Menggunakan Sensor Fotodioda," vol. 2, no. 1, p. 8, 2013.

[5] T. K. G. Darah, "Skripsi Diajukan Untuk Memenuhi Persyaratan Memperoleh Gelar Sarjana Keperawatan (S.Kep),” p. 125, 2009.

[6] Hendrayudi, Pemrograman Delphi 8.0. Yrama Widya, 2008. 